\title{
Die Puriteine en hulle siening van seksualiteit
}

\author{
P.J. de Bruyn
}

Dept. Dogmatologie en Ekklesiologie

Potchefstroomse Universiteit vir CHO

POTCHEFSTROOM

\begin{abstract}
The Puritans and their view on sexuality

As a result of the fact that the fundamental principles of the Reformation were not fully realised everywhere, Puritanism originated with the purpose of establishing a 'pure church' and a 'pure life'. Regarding sexuality, Puritanism gave rise to a rigid outlook, especially in England, North America and the Netherlands. According to the Puritans sexual intercourse was to occur frequently within the marital relationship, and it was considered as a transgression when this was not the case. Extramarital as well as premarital sexual intercourse was absolutely forbidden. Should it have occurred, the transgressors were severely punished - in some cases the death penalty was even pronounced! Seen as a whole, the Puritan view on sexuality within a marital relation was, however, more in line with the Scriptural view than those of the Reformers. The Puritan view on extramarital and premarital sexual intercourse was in line with that of the Reformers and with Scripture. The way, however, in which the Puritans punished transgressors was contrary to the gospel of Christ.
\end{abstract}

\section{Inleiding}

Tot en met die Hervorming was daar in die Roomse Kerk slegs een amptelike siening van seksualiteit en dit was dié van Augustinus wat later deur Gratianus, Petrus Lombardus en Thomas van Aquino bevestig is en uiteindelik deur die Konsilie van Trente gesanksioneer is. Die siening het daarop neergekom dat geslagsgemeenskap wesenlik sondig is maar verskoonbaar is as dit in die huwelik plaasvind met die oog op die verwekking van kinders (De Bruyn, 1982:29-37).

Hierdie siening is ten dele deur Luther en Calvyn oorgeneem in die sin dat 
hulle geslagsgemeenskap nog steeds beskou het as 'n daad wat op sigself sondig is (Luther, 1962:49; 1966:10; 1973:26; Calvyn, 1978:152; 1985:383). Tog dui hulle uitsprake daarop dat hulle dit nie net as verskoonbaar beskou het as dit binne die huwelik plaasvind met die oog op die verwekking van kinders nie, maar ook as dit in die huwelik plaasvind met die oog op die bevrediging van man en vrou se seksuele behoeftes (Luther, 1966:9; 1973:26, 27; Calvyn, 1972:115; 1985:383). Daarby het hulle die selibaat ten sterkste veroordeel omdat dit volgens hulle juis aanleiding kan gee tot owerspel (Luther, 1973:24; 1974:95; Calvyn, 1966:112, 113; 1972:116-117; 1978:153, 154).

Die eerste vraag wat in die lig van voorgaande ontstaan, is watter siening daar oor seksualiteit in die reformatoriese kerke na die Hervorming was. Aangesien die Puriteine in hierdie tyd - veral in die sewentiende en agtiende eeu - in die Christelike kerke 'n besonder sterk stroming verteenwoordig het, word hier spesifiek aandag gegee aan hulle siening en optrede ten opsigte van seksualiteit.

'n Tweede vraag wat met die vorige een verband hou, spruit voort uit die bewering van Rinzema (1972:79) dat in die Victoriaanse onderdrukking van die normale seksuele lewe die fatsoenmoraal van die Puriteine oorgeneem is, maar sonder die daadwerklike belewing van die Christelike godsdiens wat by die Puriteine ook die fondament van hulle seksuele moraal gevorm het. Laat Rinzema reg geskied aan die Puriteine deur van hulle moraal, insluitend hulle seksuele moraal, as 'n fatsoenmoraal te praat? En wat is die implikasie daarvan dat die seksuele moraal van die Victoriaanse tyd 'n moraal sonder die godsdienstige fundering van die Puriteine was, veral in die lig van die seksuele revolusie wat in die twintigste eeu sou volg?

Derdens is hierdie onderwerp van besondere belang aangesien daar tans ook in Suid-Afrika 'n situasie aangetref word wat in 'n bepaalde opsig ooreenstemming toon met dié van die Puriteine, naamlik dat ekonomiese druk tot 'n uitgestelde huweliksluiting aanleiding gee (vgl. Elliot, 1975:30, 31). Vanselfsprekend het so 'n situasie altyd 'n uitwerking na een of ander kant toe op veral jongmense se belewing van hulle seksualiteit. Die vraag is nou: het die Puriteine se hantering van die probleem enige betekenis met die oog op die huidige situasie?

Daar sal veral toegespits word op die Puriteine in Engeland, die VSA en Nederland. Eers sal aangedui word wat die herkoms van die Puriteine is en wat die kenmerke van hulle godsdienstige lewe was. Daarna sal aan hulle siening van seksualiteit aandag gegee word. 


\section{Die Puriteine}

\subsection{Ontstaan en uitbreiding van die Puritanisme}

Die Anglikaanse Kerk in Engeland was aanvanklik "gereformeerd in de leer, (maar) rooms in de vormen" (Berkhof, 1950:238). Dié Roomse oorblyfsels het veral tot openbaring gekom in die ampsdraers se kleredrag en in die liturgie (Stoeffler, 1965:27). Teen die Roomse elemente in die kerk het beswaarde Protestante veral tussen 1559 en 1567 in verset gekom en gestry vir die verkryging van 'n "pure church" en 'n "pure life" (Terlaak Poot, 1960:547; 1964:33; Stoeffler, 1965:27) - vandaar die naam Puriteine (vgl. Algra, 1965: 20).

Daarmee is die aandag reeds gevestig op die saak wat vir hierdie studie van groot belang is, naamlik die strewe na 'n "pure life" wat beteken dat daar gestreef is na 'n hoogstaande sedelike lewe (James, 1968:166).

Die Puritanisme moet gesien word as 'n uitvloeisel van die Hervorming (James, 1968:161; Latourette, 1953:808, 813). Veral Calvyn en Knox het 'n groot aandeel gehad in die ontstaan en groei van die Puritanisme in Engeland (Campbell, 1896:141-143; Emerson, 1977:27; Algra, 1965:21). Vanselfsprekend was die aandeel van Calvyn hoofsaaklik indirek vanweë sy invloed op Knox en andere, terwyl Knox self baie meer direk daarby betrokke was, sodat Ridley (1968:236) van hom kan sê: "Knox was not only the father of the Scottish Reformation, but also one of the founders of English Puritanism".

Met die kolonisasie van Noord-Amerika aan die begin van die sewentiende eeu het 'n sterk gemotiveerde Puriteinse groep uit Engeland en Nederland daarheen vertrek (Berkhof, 1950:243), waar hulle hulle veral in New England gevestig het en Plymouth gestig het (Campbell, 1895:6). Daar het die ware karakter van die Puritanisme die duidelikste tot openbaring gekom. En as Berkhof (1950:243) sê dat die Protestantisme sy wêreldposisie te danke het aan die ontwikkeling op kerklike gebied in Amerika, dan impliseer dit dat ook 'n groot invloed van die Puriteine uitgegaan het. Campbell (1895:1) gaan selfs so ver om die Puritanisme te noem "de grootste zedelijke en staatkundige kracht der nieuwere tijden, en wel bepaald met betrekking tot zijn invloed op het volk en de instellingen der Vereenigde Staten".

Hoewel Puriteinse lewensbeskouings reeds in die tweede helfte van die sestiende eeu in Nederland aangetref is, het dit as 'n bepaalde stroming daar eers duidelik vorm aangeneem in die periode wat op die Sinode van Dordrecht in 1618/1619 gevolg het. Hierdie stroming of beweging, wat dikwels aangedui 
word met die uitdrukking "Nadere Reformasie", het volgens Lekkerkerker (1955:557) onder andere ontstaan "als waarschuwende reactie tegen de leerheiligheid, die zich na die synode van Dordrecht dreigde meester te maken van de Kerk en de prediking". Die leidende figure van hierdie beweging het sterk nadruk gelê "op de groei en de vrucht van het geestelijke leven, van het leven als Christen" (Lekkerkerker, 1955:557). Van der Linde (1957:9) beskryf die "Nadere Reformasie" as "de radicale, gereformeerde reformatie, die 'preciesheid' wenst in plaats van vrome (onvrome) algemeenheden, een piëtisme dus, een bewust wijden van het hele leven aan God". Elders sê Van der Linde (1960:128): "We zouden de Nadere Reformatie het Nederlands Puritanisme kunnen noemen".

Van der Linde (1957:10) maak ook melding van die feit dat "in de kring van die nadere reformatie engelse en schotse outeurs gretig gelezen werden", en dan het hy spesifiek die oog op die Puriteinse outeurs. Bakhuizen van den Brink en Dankbaar (1968:48) verklaar selfs van Willem Teellink (1579-1629), een van die leidende figure van die Nadere Reformasie: "Teellink leerde het piëtistisch Puritanisme in Engeland en bracht het naar Nederland over" (vgl. Algra, 1965:27-31).

In die lig van hierdie uiteensetting is dit duidelik dat die Puriteine in die sestiende en sewentiende eeu 'n sterk stroming in Engeland, Amerika en Nederland was (Campbell, 1895:4), wat nie beteken dat daar in ander lande nie ook Puriteinse lewensbeskouings aangetref is nie.

\subsection{Algemene kenmerke van die Puriteine se godsdienstige lewe}

\subsubsection{Streng aan die Skrif gebonde}

Die godsdiens van die Puriteine was geheel en al gegrond op die Bybel. Van kerklike reëls en tradisies wou hulle niks weet as dit nie direk op die Bybel gegrond is nie (Whiting, 1968:443). Whiting (1968:443) sê in dié verband: "The Bible was the guide of their actions, especially the Old Testament". Hoewel hulle die Nuwe Testament nie in die minste te na gekom of opsy geskuif het nie en deur en deur Christelik in hulle lewensuitkyk was, is die besondere plek wat die $\mathrm{Ou}$ Testament in hulle lewe ingeneem het, tog opvallend (Whiting, 1968:443).

1 Daar word soms besware geopper teen die gebruik van hierdie uitdrukking. Vgl in dié verband Brienen (1974:220-221); Bakhuizen van den Brink en Dankbaar (1968:49). 
Die betekenis wat die Puriteine deur hulle besondere binding aan die Skrif gehad het, word deur Torrance (1982:277) soos volg aangedui: "In this way Puritanism was to exert an enormous creative influence on the religion of England and Scotland and (not least on Presbyterianism) throughout the English-speaking world".

\subsubsection{Geen askete nie}

Die Puriteine word dikwels verkeerdelik voorgestel as 'n groep askete en in een asem genoem met mense met 'n Victoriaanse lewenshouding. Dit is beslis verkeerd (Scanzoni, 1968:33; Bell, 1966:21).

Morgan $(1966: 63,64)$ dui hulle lewenshouding duidelik soos volg aan:

The Puritans were a much earthier lot than their modem critics have imagined ... The Puritans were neither prudes nor ascetics. They knew how to laugh, and they knew how to love. But it is equally clear that they did not spend their best hours in either love or laughter. They had fixed their eyes on a heavenly goal, which directed and informed their lives. When earthly delights dimmed their vision, it was time to break off. Yet even on this side of the goal there was room for joy.

\section{Die Puriteine se siening van seksualiteit}

Op grond van hulle streng gebondenheid aan die Bybel was die Puriteine absoluut fanaties gekant teen alle geslagsgemeenskap buite die huwelik ${ }^{2}$ (Rutman, 1977:46). Dit geld van die Puriteine in Engeland, Amerika en Nederland.

\subsection{Die Puriteine in Engeland}

Die Puriteine in Engeland het 'n hoë waardering vir die huwelik gehad. Perkins (1970:420; vgl. Haller, 1965:120), wat geleef het van 1559 tot 1602 en as die vader en een van die grootste leiers van die Engelse Puriteine beskou kan word (Van Baarsel, 1975:100, 169; Malan, 1981:8), het beklemtoon dat die huwelik noodsaaklik is "to avoid fornication and consequently to subdue and slake the burning lusts of the flesh (1 Cor. 7:2,9)". Dit was ook die siening van Watson $(1990: 154,160,161)$ wat as een van die populêrste predikers in London in die Puriteinse periode beskou is. Alle groepe mense, sonder uitsondering, het die vryheid om te trou as hulle dit verkies, "but for them

2 Hier word nie aandag gegee aan die wyse van huweliksluiting nie omdat dit in verskillende lande en gemeenskappe van mekar verskil. 
which cannot abstain, it is by the express commandment of God necessary (Heb. 13:4; 1 Cor. 7:9)" (Perkins, 1970:420; vgl. Haller, 1965:120). Perkins (1972:411-413) was dan ook van oordeel dat mense wat voorheen in die Roomse Kerk monnike en nonne was en met 'n eed beloof het om nie te trou nie, so 'n eed sonder gewetenskwelling kon verbreek omdat dit 'n eed is wat in stryd is met die Skrif en in die besonder met 1 Korintiërs 7:9.

Teenoor hierdie waardering van die huwelik het hulle alle buite-egtelike geslagsgemeenskap skerp veroordeel. Perkins (1972:30, 31) sluit in hierdie verband aan by Paulus se uitspraak: "Elke ander sonde wat 'n mens doen, vind buite die liggaam plaas, maar iemand wat seksueel losbandig lewe, vergryp hom aan sy eie liggaam" ( 1 Kor. 6:18). ${ }^{3}$ Volgens Perkins beteken die uitspraak dat by buite-egtelike geslagsgemeenskap die liggaam nie net die instrument is waarmee gesondig word nie, maar ook die objek wat deur die betrokke sonde besoedel word. Dit is die enigste sonde waarvan so iets gesê word en daaron moet dit as 'n buitengewoon ernstige sonde gesien word.

Rutman (1977:47) sê ook van die Puriteine in Engeland: "They left no doubt that sexual intercourse outside marriage was universally condemned". Losheid van sedes het hulle as 'n doodsvyand van die Hervorming beskou. Die voortsetting van die reformasie in Engeland kon in die oë van die Puriteine alleen plaasvind "wanneer de zeden der natie veranderen" (Algra, 1965:20). Daarom: "If the shape of the society was to be maintained, Pauline morality had to be enforced" (Rutman, 1977:47). Algra (1965:22) sê dat selfs die leër van die Puriteinse Cromwell hom in sedelikheid van alle ander leërs onderskei het. Spesifiek word vermeld dat die vroulike eer "tijdens de langdurige soldatenregering heilig werden geacht ... Geen dienstmaagd had over ruwe liefkozingen van de roodrokken te klagen" (Algra, 1965:22).

Die erns wat die Puriteine in Engeland met gehoorsaamheid aan die Woord van God ook op seksuele gebied gemaak het, moet egter nie as 'n soort wettisisme of moralisme verstaan word nie. Van Baarsel (1975:250) en Shaw (1982:148149) toon duidelik aan dat, spesifiek in die teologie van Perkins, gehoorsaamheid verstaan moet word as nuwe gehoorsaumheid wat voortvloei uit die verlossing deur Christus en die werking van die Heilige Gees (vgl. Janse

3 Dit is moeilik om te bepaal presies wat Paulus met hierdie uitspraak bedoel. Kommentare en ander werke wat nagegaan is, het getoon dat daar minstens tien verskillende verklarings - insluitend dié van Perkins - van hierdie uitspraak gegee word (vgl. hieroor De Bruyn, 1982:300-301). Almal is dit egter eens dat Paulus porneia hier as 'n baie emstige oortreding aandui. 
van Rensburg, 1991:58, 59). In die lig hiervan is dit verstaanbaar dat Van Baarsel (1975:230) Perkins "een gezonde Puritein" noem en van hom kan sê: "Van alle rigorisme en ascetisme is hij afkeerig". Daarom was Perkins ook van oordeel dat die Christen alles wat God aan die mens gegee het om te geniet, "vrij en mild tot Christelijk genot en genoegen" mag aanvaar (Van Baarsel, 1975:230).

Hierdie nuwe gehoorsaamheid, ook op seksuele gebied, is deur die besonder praktiese en aktuele prediking van die Puriteinse predikante by lidmate tuisgebring (Stoeffler, 1965:27-29).

\subsection{Die Puriteine in Amerika}

Om die Puriteine in Amerika se beskouing van en optrede met betrekking tot geslagsgemeenskap buite die huwelik reg te kan evalueer, is dit wenslik om eers na te gaan wat hulle standpunt oor geslagsgemeenskap binne die huwelik was.

Geslagsgemeenskap binne die huwelik was volgens hulle 'n absolute moet. Selfs die huweliksluiting was volgens hulle nie afgehandel voor geslagsgemeenskap nie eers plaasgevind het nie. Eers daarna is die egpaar beskou as wettig getroud (Morgan, 1966:34).

As die huwelik voltrek is, was gereelde geslagsgemeenskap 'n absolute moet. Hoe streng hulle beskouing en optrede in die verband was, blyk uit die mededeling van Hunt (1960:201) dat 'n sekere James Mattock in die First Church of Boston afgesny is as lidmaat van die kerk omdat hy twee jaar lank geen geslagsgemeenskap met sy vrou gehad het nie. Sy optrede is bestempel as "unnatural and unchristian".

Twee redes word aangedui vir die Puriteine se eis van gereelde geslagsgemeenskap in die huwelik. Die eerste is "for its role in relieving sexual frustration and thus cutting down on perversion" (Elliot, 1975:35). Daarom is van 'n wewenaar en weduwee verwag om so gou as moontlik weer te trou (Ziff, 1973:120). Die tweede rede was omdat die Puriteine baie handlangers nodig gehad het en baie kinders gevolglik voortgebring moes word (Ziff, 1973:120).

Maar terwyl geslagsgemeenskap binne die huwelik volgens die Puriteine ten strengste gebode was, was geslagsgemeenskap buite die huwelik ten strengste verbode. Rutman (1977:46) stel dit so: "Toward sexual intercourse outside marriage the Puritans were as frankly hostile as they were favorable to it in marriage". 
Alle voorhuwelikse en buite-egtelike geslagsgemeenskap is deur hulle pertinent hoerery genoem (Morgan, 1966:33, 35). Daarby het hulle dit nie net met woorde afgekeur nie, maar die skuldiges geestelik en liggaamlik gestraf. Scanzoni (1968:34) beskryf hulle optrede in gevalle van voorhuwelikse geslagsgemeenskap soos volg:

Church records of one town show that public confession of fornication had to be made by any couple who had a child borm less than seven months after marriage. Couples feared the damnation of the infant if they failed to confess. In several cases of premature birth at Plymouth, the wife was placed in stocks to witness the public whipping of her husband.

In gevalle van owerspel was die optrede, volgens Morgan (1966:41), nog strenger:

To comply with the laws of God, Massachusetts, Connecticut, and New Haven made adultery a capital offence, but they seem to have carried out that punishment only three times. For the most part they sentenced offenders to fines, whippings, brandings, the wearing of the letter ' $A$ ', ${ }^{4}$ and symbolical executions in the form of standing on the gallows with a rope about the neck.

In alle gevalle van geslagsgemeenskap buite die huwelik moes die skuldiges hulle skuldbelydenis op skrif stel. Die eersvolgende Sondag is dit dan aan die gemeente voorgelees. Daarna moes daaroor gestem word. Word dit aanvaar, behou die persoon sy of haar lidmaatskap van die kerk. Word dit nie aanvaar nie, word hy of sy geëkskommuniseer (Hunt, 1960:201-202).

Die motivering vir hierdie streng optrede was primêr 'n buitengewone erns in die strewe na gehoorsaamheid aan die gebooie van God. Daarby moet in gedagte gehou word dat daar in dié tyd in die prediking 'n verskuiwing van die reformatoriese aksent op die regverdigmaking na 'n beklentoning van die heiligmaking was (Tumbull, 1974:23). Van John Cotton (1584-1652), predikant van die First Church of Boston, New England, sê Turnbull (1974:23): "Sanctification or holiness became his theme in preaching." Vanselfsprekend sou hierdie prediking ook 'n duidelike invloed op die Puriteine se beskouing oor seksualiteit in die algemeen en voorhuwelikse geslagsgemeenskap in die besonder gehad het.

In noue aansluiting by die voorgaande was daar ook 'n verdere rede vir hulle strewe na kuisheid en dit word deur Morgan (1966:174) soos volg aangedui: "The church was thus turned into an exclusive society for the saints and their

Die 'A' staan vir adulterer. 
children. Instead of an agency for bringing Christ to fallen man it became the means of perpetuating the gospel among a hereditary religious aristocracy". Om hulleself in hierdie posisie te beskerm, moes daar teen die skuldiges opgetree word, want, in die woorde van Rutman (1977:47), "breaches must be punished lest the community suffer the wrath of God". Ook Bell (1966:19) beklemtoon hierdie motivering vir die Puriteine se optrede as hy sê: "In Puritan theology, premarital sexual behaviour was interpreted as succumbing to the temptations of the flesh - behavior not found among the "chosen"'.

Om die hele situasie verder in die regte perspektief te sien, moet onthou word dat huwelike onder die Puriteine glad nie op 'n besonder vroeë leeftyd gesluit is nie. Elliot (1975:30, 31) skets die situasie soos volg:

Throughout the second half of the seventeenth century the average age at marriage was between twenty-six and twenty-eight years for men and between twenty-four and twenty-six years for women, with marriage ages for first marriages of both sexes often reaching into the middle thirties.

Die rede vir die huwelik op so 'n hoë ouderdom was hoofsaaklik ekonomies van aard: die nadruk het sterk geval op produktiwiteit; daarom moes die dienste van 'n seun of dogter so lank as moontlik behou word voor hy of sy die huis verlaat om self ' $n$ huishouding te begin. Ook was daar geen sprake daarvan dat 'n man kon trou en saam met sy ouers in dieselfde huis woon nie (Elliot, 1975:31).

Hierdie situasie van 'n uiters streng verbod op voorhuwelikse geslagsgemeenskap aan die een kant en 'n ekonomiese sisteem wat 'n huwelik op 'n vroeë ouderdom feitlik uitgesluit het aan die ander kant, het, volgens Elliot (1975:34, 35), vir die jongmense ernstige sedelike probleme geskep en selfs in 'n stadium tot die uitbarsting van 'n vlaag van seksuele wangedrag in Plymouth aanleiding gegee (vgl. ook Bell, 1966:20). Maar selfs dit kon die beskouing van die Puriteinse gemeenskap oor voorhuwelikse geslagsgemeenskap en die toepassing van die strawwe by oortreding nie verander nie. "They would not yield their control of the land and of the lives of their children simply because of the sexual frustrations of the young" (Elliot, 1975:36).

Dit is duidelik dat die Puriteine in die VSA erns daarmee gemaak het om hulle lewe, ook wat seksualiteit betref, in te rig volgens die Woord van God. Trouens, juis ten opsigte van die seksuele word dit duidelik in hoe 'n mate hulle erns gemaak het met die praktiese uitlewing van die voorskrifte van God se Woord. Binne die huwelik moes geslagsgemeenskap gereeld plaasgevind het, en dit is baie duidelik dat dit nie net plaasgevind het met die oog op die verwekking van kinders nie, maar ook om die mens se normale seksuele 
behoeftes te bevredig. Daarteenoor is voorhuwelikse geslagsgemeenskap en buite-egtelike geslagsgemeenskap met groot beslistheid afgewys - ook op grond van die bepalings in God se Woord. Selfs in gevalle waar jongmense nie meer so jonk was nie en om ekonomiese redes nie kon (of toegelaat is om te) trou nie, is geen toegewings gemaak of verskonings aanvaar nie omdat God se Woord voorhuwelikse geslagsgemeenskap afwys. Die wyse waarop oortreders gestraf is, laat egter ernstige bedenkinge by ' $n$ mens ontstaan. Dit skep veel eerder die indruk van wêreldse straf as van kerklike tug wat toegepas moet word "ooreenkomstig die geestelike bestuurswyse, wat ons Here ons in sy Woord geleer het" (NGB art. 30).

\subsection{Die Puriteine in Nederland}

Die siening van voorhuwelikse geslagsgemeenskap by die breë bevolking in Europa, en dus ook in Nederland aan die begin van die sestiende eeu, blyk duidelik uit die volgende twee mededelings van Van Ussel (1971:44): "De premaritale coitus was immers als sociaal systeem geïnstitutionaliseerd ... De acties tegen de premaritale coitus werden lange tijd door de bevolking zelfs als immoreel beoordeeld".

Met hierdie stand van sake sou die Hervormers, en veral hulle Puriteinse navolgers, geen genoeë neem nie. Hulle was immers met woord en daad gekant teen alle voor- en buite-egtelike geslagsgemeenskap.

In Nederland het veral die Puriteinse element onder die gereformeerdes in die tweede helfte van die sestiende eeu daartoe bygedra dat die bordele wat voor die Reformasie opgerig is sonder effektiewe beswaar deur die Roomse Kerk gesluit is. So is dit bekend dat in Amsterdam al die bordele in 1578 gesluit is (Lewandowski \& Van Dranen, 1933:131). Daarbenewens is daar, volgens Lewandowski en Van Dranen (1933:131-132), die volgende praktyke deur die toedoen van die Puriteine in werking gestel:

... strenge straffen [worden] ingesteld tegen het samewonen van ongehuwde personen of het vobr den tijd defloreeren van de bruid. Zoo word op het 10en Mei 1650 te Amsterdam gehouden Puriteinsch congres bepaald, 'dat iedere koppelaar of houder van een bordeel moest worden afgeranseld, te pronk gesteld en gebrandmerkt met een B.' - Bawd namelijk beteekent koppelaar en uit godsdienstige verdraagzaamheid (!) brandmerkte men deze lieden niet met het geheele woord, doch slechts met de beginletter. Hielp zelfs dit niet en werden de zedeloose praktijken voortgezet, dan kregen de schuldigen de doodstraf. 
Maar selfs hierdie besonder streng maatreël kon nie oral in Nederland 'n einde maak aan 'n diepgewortelde praktyk van buite-egtelike geslagsgemeenskap en prostitusie nie. Trouens, juis in die Puriteinse tyd was daar, volgens Van der Ven (1929:49-53), 'n praktyk in dele van Nederland bekend as "nachtvrijen" en "venster-vrijen" waarvolgens voorhuwelikse geslagsgemeenskap met medewete van ouers en ander familielede plaasgevind het.

Hoewel almal in dié gemeenskappe geweet het dat dit verkeerd en sondig is, het almal dit toegelaat en selfs doelbewus die geleentheid geskep dat dit kon gebeur. So word in hierdie verband van die mense in die "zeer kerksche Staphorst-Rouveen" wat "den Sabbat heiligt en den Heere vreest" en "uitsteekt als een licht op den kandelaar", die volgende verklaar:

Maar al die streng-dogmatische levensopvattingen verhoeden niet dat er gezondigd word tegen het zevende gebod. Gezondigd niet in de verborgenheid, maar gezondigd onder die sanctie van de ongeschreven wetten der jongelingschap. Gezondigd met medeweten van zusters en broeders, vader en moeder, ooms en tantes, ja van die geheele clan-bevolking. Gezondigd tegen God en Zijn gebod in de oogen van een ieder, die zich in ons Nederland 'kerkelijk' noemt en wel gezondigd door een groep van de meest kerkschen onder de kerkelijken, door volgelingen van de mees orthodoxe predikanten (Van der Ven, 1929:53-54).

Teen hierdie praktyke in dié bepaalde streke is van kerklike kant streng opgetree, want volgens Van der Ven (1929:54) is daar in 1660 in die "Staphorster Kerkeboek" na hierdie praktyk van jongmense in daardie omgewing verwys as "onordentlicke bijeenkomsten" waarteen "de kerckeraat sich genoodsaact vind om kerklick tegens die soodanige te procedeeren, want na het bevel Pauli wij gehouden sijn ons te onttrecken van een ijgelick Broeder, die ongeregelt wandelt".

Alles dui egter daarop dat hierdie praktyk, ondanks die streng Puriteinse maatreëls en ondanks voortdurende kerklike protes en tugmaatreëls, in Staphorst en Rouveen tot aan die begin van die twintigste eeu bly voortbestaan het. Dit blyk daanuit dat 'n "gecombineerde vergadering van onderskeidene voorgangers op kerkelijk en burgerlijk terrein" wat op 19 Mei 1920 (260 jaar na 1660) te Staphorst gehou is, hulle verplig gevoel het om die mense in daardie omgewing ernstig te vermaan oor presies dieselfde sondige praktyk. Trouens, volgens die stuk waarin hulle hulle vermaning uitgespreek het, het die situasie daar sodanig vererger dat geslagsgemeenskap toe nie meer net plaasgevind het by twee jongmense wat reeds van voomeme was om in die huwelik te tree nie, maar "dat een jongeling en jongedochter reeds bij de eerste kennismaking des 
nachts met elkaar op't bed vertoeven en ongeoorloofde gemeenschap oefenen" (Van der Ven, 1929:55).

Die 'kerklike norm' wat voorhuwelikse geslagsgemeenskap verbied, is wel formeel erken. Daarom was daar ook "een formele schuldbekentenis bij overtreding ervan". So 'n skuldbelydenis was ook die voorwaarde vir die kerklike inseëning van die huwelik (Timmer, 1974:193).

Tog moet in gedagte gehou word dat genoemde praktyk van "nachtvrijen" slegs tot bepaalde streke, veral in die platteland, beperk was (Knap, 1930:68; Timmer, 1974:192).

Evenhuis (1967:103) sê uitdruklik dat die kerkraad van die Gereformeerde Kerk Amsterdam dit as hulle taak beskou het om nougeset te waak "dat bruidegom en bruid niet voor hun trouwdag met elkaar naar bed gingen". In ander stede is daar van owerheidsweë aan die egpaar wat wil trou, gevra of daar "vleesschelijcke conversatie" tussen hulle plaasgevind het. Indien wel, is hulle beboet. Die klassis het daarop aangedring dat daar ook in Amsterdam so opgetree moes word, maar die betrokke owerheid wou nie. Die gevolg was dat daar vir die voorkoming van voorhuwelikse geslagsgemeenskap 'n groter verantwoordelikheid op die kerkraad geplaas is. "De waakzaamheid van de kerkeraad was hier dus extra nodig en het wordt nogal eens in de kerkeraad gerapporteerd, waarbij opvalt hoe goed de kerkeraad op de hoogte was" (Evenhuis, 1967:103).

Voorhuwelikse geslagsgemeenskap is ook deur die kerk as hoerery bestempel (Evenhuis, 1967:107, 297).

As 'n jongman met 'n meisie geslagsgemeenskap gehad het en swangerskap daarop gevolg het, kon hy volgens die burgerlike wet "ervan afkomen door het betalen van een afkoopsom. Maar de kerk heeft altijd geëist dat zulk een jonge man het meisje zou trouwen en de kerk krijgt daarvoor weer een goede aantekening! De Amsterdamse classis schreef dit nadrukkelijk voor op grond van Ex. 22:16 ... In het algemeen kon elk bedrogen meisje op de kerkeraad rekenen" (Evenhuis, 1967:104).

Voorhuwelikse geslagsgemeenskap is deur die owerheid in Amsterdam gestraf met boete, gevangenisstraf of verbanning, afhangende van omstandighede en vorige oortredings, en die kerkraad het toegesien dat die strawwe wel toegepas is (Evenhuis, 1967:107-109).

Vermeldenswaardig is die gebeure met Rembrandt. Na die dood van Saskia het hy buite-egtelik saamgeleef met Hendrikje Stoffels, en uit die verhouding is 'n kind gebore. Met die kerklike tug is daar, volgens beskikbare getuienis, slegs 
teen Hendrikje opgetree, maar nie teen Rembrandt nie. Die rede vir die opvallende inkonsekwensie is nie bekend nie. Die kind is wel na verloop van tyd gedoop (Evenhuis, 1967:296-297).

Oor die geheel beskou, kan dus wel met vrymoedigheid gesê word dat die Puriteine met hulle streng reëls en maatreëls onteenseglik daartoe bygedra het dat ' $n$ buitengewoon kuise lewe in Nederland gelei is, dermate dat hulle besondere kuisheid in dié tyd selfs in die buiteland bekendheid verkry het (Campbell, 1895:188-189; 1896:338). Dit moet egter onmiddellik bygevoeg word dat dit nie van die hele Nederland van dié tyd gegeld het nie. Waarskynlik het die berigte oor die situasie in Staphorst en Rouveen, waar daar 'n duidelik botsing was tussen die Puriteinse leer en hulle lewe, die buiteland nie bereik nie. Tog moet dit as 'n uitsondering gesien word en 'n mens sal die Puriteine ' $n$ onreg aandoen deur hulle leer en lewe te beoordeel in die lig van wat in ' $n$ beperkte deel van Nederland plaasgevind het.

\section{Beoordeling}

By 'n beoordeling van die Puriteine se siening van seksualiteit moet hulle gebondenheid aan die Bybel baie hoog waardeer word. Daarin het hulle die riglyne gevind wat hulle laat verstaan het dat geslagsgemeenskap voor en buite die huwelik nooit mag nie, maar binne die huwelik gereeld moet.

Met die oog op die eerste vraag wat in die inleiding gestel is, kan in die lig van die voorgaande uiteensetting geantwoord word dat die Puriteine in hulle beskouing oor seksualiteit in 'n sekere sin nader aan die Skrif was as die Hervormers. Luther en Calvyn het geslagsgemeenskap in die huwelik nog beskou as wesenlik sondig, maar tog verskoonbaar, veral as dit plaasvind met die oog op 'n nageslag. Die Puriteine het geslagsgemeenskap in die huwelik egter hoegenaamd nie as sondig beskou nie, selfs nie wanneer dit plaasvind bloot met die oog op die bevrediging van mekaar se seksuele behoeftes en sonder enige gedagte aan die verwekking van kinders nie. So 'n beskouing sluit baie nouer aan by wat Paulus in 1 Korintiërs 7:2-5 en 9 sê as die siening van Luther en Calvyn (vgl. ook Spr. 5:15-20; Pred. 9:9; Hoogl. 7:7-9).

In hulle siening oor voorhuwelikse en buite-egtelike geslagsgemeenskap was die Puriteine ten volle in ooreenstemming met die Skrif en ook met die siening van Luther en Calvyn. Vanselfsprekend geld dit nie van die streke van Staphorst en Rouveen in Nederland nie. Daar het die Christene duidelik in stryd met Skrif en belydenis opgetree met blywende skadelike gevolge. Soos reeds aangedui is, het ' $n$ mens hier met 'n uitsondering te doen en mag hierdie optrede nie sonder meer aan die Puriteine as stroming verbind word nie. 
Wat die tweede vraag in die inleiding betref, is dit duidelik dat Rinzema die Puriteine 'n onreg aandoen deur van hulle seksuele moraal as ' $n$ fatsoenmoraal te praat. Hulle het immers werklike erns daarmee gemaak om ook op seksuele gebied die voorskrifte van God se Woord konkreet en prakties uit te leef en hulle het dit beslis nie bloot ter wille van fatsoen gedoen nie.

In die lig van die studie van Hunt (1960:267, 275), Crow (1971:25), Van Ussel (1971:72, 81, 92, 101, 147, 161, 163), Bullough (1976:542-543), Esterhuyse (1980:23-31) en andere is dit duidelik dat Rinzema reg is as hy sê dat daar in die Victorianisme aan die Puriteinse siening van kuisheid vasgehou is maar sonder die godsdienstige fundering daarvan deur die Puriteine (vgl. ook Breevoort, 1936:30, 31). Dit beteken dat 'n mens in die Victorianisme van die negentiende eeu in werklikheid in die breë volkslae 'n ontkerstende kuisheid 5 aangetref het wat in die twintigste eeu tydens die seksuele revolusie sou oorgaan na 'n ontkerstende onkuisheid - iets wat 'n mens eintlik kon verwag het van 'n kuisheid wat nie op 'n godsdienstige fondament rus nie.

Die derde probleem wat in die inleiding gestel is, is dié van uitgestelde huweliksluiting vanweë ekonomiese druk. Die probleem het veral sterk na vore gekom by die Puriteine in die VSA. Dit is duidelik dat daar van die jongmense verwag is om selfbeheersing as deel van die vrug van die Heilige Gees (Gal. $5: 22$ ) te beoefen en nie toe te laat dat hulle seksuele drange die oorhand oor hulle kry nie. Dat die standpunt nie altyd so geredelik aanvaar is nie, blyk uit die verset van die jongmense in Plymouth daarteen (Bell, 1966:20; Elliot, 1975:34-36). Tog is daar in die lig van die Skrif ook tans geen ander weg moontlik as dié wat die Puriteine aan hulle kinders voorgehou het nie, naamlik selfbeheersing. Om 'n spesifieke sonde oogluikend toe te laat soos in Staphorst en Rouveen in Nederland gebeur het, beteken dat die lewe volgens daardie

Van Ussel (1971:78-80) vestig die aandag daarop dat die skeefgetrokke kuisheidsideaal van die Victorianisme nie primêr van die kerke afkomstig was nie maar van die burgery. Veral opvoedkundiges en medici - en nie soseer predikante nie - het 'n groot rol gespeel in die vestiging van die Victoriaanse siening van kuisheid (Van Ussel, 1971:101, 147, 161, 163). Dit is ook opvallend dat die boek van Breevoort (1936:30,31), waarin sy vertel watter verskrikJike siektes en ellendes 'n persoon kan opdoen wat masturbasie beoefen - iets wat later geblyk het "grove onzin" te wees (Weatherhead, 1950:127) - in 'n voorwoord baie sterk aanbeveel is deur dr. A. Dupont. Hy was 'n geneesheer-generaal in Nederland en skrywer van die boek Het huwelijk (1935; 9de druk), wat in sy oorspronklike vorm in die negentiende eeu verskyn het. In hierdie boek huldig hy dieselfde siening as Breevoort. 
sonde naderhand deel van die betrokkenes se bestaan word. As almal iets doen wat verkeerd is, word die verkeerde in die kultuurpatroon opgeneem en pas die gewete hom daarby aan (Aalders, 1965?:155) - soos wat in die betrokke dele in Nederland inderdaad die geval was.

Tog is met die verwysing na die noodsaaklikheid van selfbeheersing vir die jong Christene op seksuele gebied nie alles gesê nie. 'n Mens kan immers nie ontken dat die situasie tans baie anders is as in die tyd van die Puriteine nie. Die hedendaagse jongmens word ongevraag tydig en ontydig gebombardeer met seksuele stimulante wat nie die geval was in die tyd van die Puriteine nie (vgl. De Ligne, 1960?:39-40). In die lig daarvan sal jongmense wel emstig moet bid vir 'n kuis lewe, hulle nie onnodig aan versoeking en verleiding moet blootstel nie, maar andersins ook nie moet toelaat dat hulle verhouding veral fisies te vinnig ontwikkel en hulle naderhand so 'n mate van intimiteit bereik dat dit bykans onmoontlik word om geslagsgemeenskap te weerstaan nie. Haas jou langsaam moet vir hulle 'n belangrike reël bly (Boshoff, 1975:16; Smuts, 1976:38). Aan die ander kant behoort ouers tans meer tegemoetkomend as die Puriteinse ouers te wees en behoort hulle hulle kinders fmansieel te help sodat die huwelik nie onnodig lank uitgestel word nie.

\section{Bibliografie}

AALDERS, W. 1965 ? In verzet tegen de tijd: een protest tegen de verwereldlijking van God en de vergoddelijking van de wereld. Den Haag: Voorhoeve.

ALGRA, H. 1965. Het wonder van de 19de eeuw: van vrije kerken en kleine luyden. Franeker : Wever.

BAKHUIZEN VAN DEN BRINK, J.N. \& DANKBAAR, W.F. 1968. Handboek der kerkgeschiedenis - 4. 3de druk. Den Haag : Bert Bakker.

BELL, R.R. 1966. Premarital Sex in a Changing Society. Englewood Cliffs : Prentice-Hall (Spectrum).

BERKHOF, H. 1950. Geschiedenis der kerk. 5de druk. Nijkerk : Callenbach.

BOSHOFF, H. 1975. As ons twee alleen is ... Brakpan : Verenigde Gereformeerde Uitgewers.

BREEVOORT, J. 1936. (Oorspronklik 1916.) Stomme zonden: een waarschuwend woord voor onze jongelieden. Kampen : Kok.

BRIENEN, T. 1974. De prediking van de Nadere Reformatie; een onderzoek naar het gebruik van de klassifikatiemethode binnen de prediking van de Nadere Reformatie. Amsterdam : Ton Bolland.

BULLOUGH, V.L. 1976. Sexual Variance in Society and History. New York/London : John Wiley. 
CALVYN (CALVIJN), J. 1966. Uitlegging van de pastorale brieven. Uit Latyn vertaal deur $H$. Schroten. Kampen : Kok.

CALVYN (CALVIJN), J. 1972. Uitlegging op den eersten en tweeden zendbrief van Paulus aan de Corinthiërs. 2de druk. Vertaal deur A.M. Donner. Goudriaan : De Groot.

CALVYN (CALVIJN), J. 1978. Het gepredikte Woord: preeken van Johannes Calvijn. 3de druk. Deel 4: Preeken over den Dekaloog. Vertaal deur J. Douma en W.H. van der Vegt. Franeker : Wever.

CALVYN (CALVIJN) J. 1985. Harmonie van de laatste vier boeken van Mozes - 2. Vertaal deur J. van den Heuvel. Kampen : De GrootGoudriaan.

CAMPBELL, D. 1895. De Puriteinen in Nederland, Engeland en Amerika. Deel 1. Uit Engels vertaal deur J.W.G. van Maanen. Sneek : Van Druten. CAMPBELL, D. 1896. De Puriteinen in Nederland, Engeland en Amerika. Deel 2. Uit Engels vertaal deur J.W.G. van Maanen. Sneek : Van Druten. CROW, D. 1971. The Victorian Woman. London : George Allen \& Unwin. DE BRUYN, P.J. 1982. Voorhuwelikse geslagsgemeenskap: 'n teologiesetiese studie. Potchefstroom : PU vir CHO. (Th.D.-proefskrif.)

DE LIGNE, A. 1960? De tijd aller tijden. Franeker : Wever.

DUPONT, A. 1935. Het huwelijk: geneeskundige wenken voor gehuwden en verloofden. 9de dnuk. Kampen : Kok.

ELLIOT, E. 1975. Power and the Pulpit in Puritan New England. Princeton : Princeton University Press.

EMERSON, E. 1977. Puritanism in America 1620-1750. Boston : Twayne Publishers.

ESTERHUYSE, W.P. 1980. Die mens en sy seksuele moraal. Durban : Butterworth.

EVENHUIS, R.B. 1967. Ook dat was Amsterdam - Deel 2: De kerk der hervorming in de gouden eeuw. Amsterdam : Ten Have.

HALLER, W. 1965. The Rise of Puritanism; the Way to the New Jerusalem as Set Forth in Pulpit and Press from Thomas Cartwright to John Lilburne and John Milton, 1570-1643. 4th printing. New York/London : Columbia University Press.

HUNT, M.M. 1960. The Natural History of Love. London : Hutchinson.

JAMES, S.V. 1968. The New England Puritans. New York/London : Harper \& Row.

JANSE VAN RENSBURG, J. 1991. 'n Kritiese ontleding van moralisme in die prediking. Bloemfontein : UOVS. (D.Th.-proefskrif.)

KNAP, J.J. 1930. Kuisheid. Uit Nederlands vertaal deur P.J. Loubser \& C. de W. Vivier. Pretoria : Van Schaik. 
LATOURETTE, K.S. 1953. A History of Christianity. New York : Harper \& Brothers.

LEKKERKERKER, A.F.N. 1955. Nadere Reformatie. (In Mönnich, C.W. red. Encyclopedie van het Christendom: Protestants deel. Amsterdam/Brussel : Elsevier. p. 557.)

LEWANDOWSKI, H. \& VAN DRANEN, P.J. 1933. Beschavings- en zedengeschiedenis van Nederland. Amsterdam : Uitgevers-maatschappij Enum.

LUTHER, M. 1962. (Oorspronklik 1522.) The Estate of Marriage. (In Pelikan, J. \& Lehmann, H.T. ed. Luther's Works. Vol. 45: The Christian in Society -2 . Translated by W.I. Brandt. Philadelphia : Muhlenberg Press. p. 11-49.)

LUTHER, M. 1966. (Oorspronklik 1519). A Sermon on the Estate of Marriage. (In Pelikan, J. \& Lehmann, H.T. ed. Luther's Works. Vol. 44: The Christian in Society -1 . Translated by J. Atkinson. Philadelphia : Fortress Press. p. 3-14.)

LUTHER, M. 1973. (Oorspronklik 1524.) Commentary on 1 Corinthians 7. (In Pelikan, J. \& Lehmann, H.T. ed. Luther's Works. Vol. 28: Commentaries. Translated by E. Sittler. Saint Louis : Concordia Publishing House. p. 3-56.)

LUTHER, J. 1974. (Oorspronklik 1530.) Die Groot Kategismus. Uit Duits vertaal deur $\mathrm{L}$. van der Westhuizen. Otjimbingue : Verenigde Lutherse Teologiese Seminarie/Kaapstad/Teologiese Seminarie van die Evangeliese Broederkerk in S.A.

MALAN, C.J. 1981. Die Nadere Reformasie. Potchefstroom : PU vir CHO. (IBC : Wetenskaplike Bydraes.)

MORGAN, E.S. 1966. The Puritan Family: Religion and Domestic Relations in Seventeenth-Century New England. 3rd ed. New York : Harper \& Row.

PERKINS, W. 1970. The Work of William Perkins. Introduced and edited by lan Breward. Appleford/Abingdon/Berkshire : Sutton Courtenay Press.

PERKINS, W. 1972. (Oorspronklik 1606). The Whole Treatise of the Cases of Conscience, Distinguished into Three Books. Amsterdam : Theatrum Orbis Terrarum.

RIDLEY, J. 1968. John Knox. Oxford : Clarendon Press.

RINZEMA, J. 1972. De sexuele revolutie: uitdaging en antwoord. Kampen : Kok.

RUTMAN, D.B. 1977. American Puritanism. New York : Norton.

SCANZONI, L. 1968. Sex and the Single Eye. Grand Rapids : Zondervan Publishing House. 
SHAW, M.R. 1982. The Marrow of Practical Divinity: a Study in the Theology of William Perkins. London : University Microfilms International.

SMUTS, M. 1976. Kampusliefde. Pretoria : NG Kerkboekhandel.

STOEFFLER, F.E. 1965. The Rise of Evangelical Pietism. Leiden : Brill.

TERLAAK POOT, L.D. 1960. Puriteinen. (In Christelijke Encyclopedie - 5 .

2de druk. Kampen : Kok. p. 547-548.)

TERLAAK POOT, L.D. 1964. De Anglicaanse Kerk. (In Van Itterzon, G.P.

\& Nauta, D. reds. Geschiedenis van de kerk - 6. 2de druk. Kampen : Kok. p. 5-71.)

TIMMER, M. 1974. Erotiek in lage landen: een geschiedenis. Kampen : Kok.

TORRANCE, J.B. 1982. Calvin and Puritanism in England and Scotland; Some Basic Concepts in the Development of "Federal Theology". (In Van der Walt, B.J. ed. Calvinus Reformator: His Contribution to Theology, Church and Society. Potchefstroom : PU vir CHO. p. 264-277.) (IRS, reeks F, nr. 17.)

TURNBULL, R.G. 1974. A History of Preaching III: from the Close of the Nineteenth Century to the Middle of the Twentieth Century. Grand Rapids : Baker Book House.

VAN BAARSEL, J.J. 1975. William Perkins: een bijdrage tot de kennis der religieuse ontwikkeling in Engeland, ten tijde van Koningin Elisabeth. Amsterdam : Bolland.

VAN DER LINDE, S. 1957. Het Gereformeerd Protestantisme. Nijkerk : Callenbach.

VAN DER LINDE, S. 1960. Nadere Reformatie. (In Christelijke Encyclopedie - 5. 2de druk. Kampen : Kok. p. 128-129.)

VAN DER VEN, D.J. 1929. Van vrijen en trouwen op 't boerenland. Amsterdam : De Spieghel.

VAN USSEL, J.M.W. 1971. Geschiedenis van het seksuele probleen. 4de druk. Meppel : Boom.

WATSON, T. 1990. (Oorspronklik 1692.) The Ten Commandments. Edinburgh : Banner of Truth Trust.

WEATHERHEAD, L.D. 1950. Het sexueele leven beheerscht door psychologie en religie. Uit Engels vertaal deur P.H. Th. Stevens. Utrecht : Bijleveld.

WHITING, C.E. 1968. Studies in English Puritanism from the Restoration to the Revolution, 1660-1688. 2nd imp. London : Frank Cass.

ZIFF, L. 1973. Puritanism in America; New Culture in a New world. New York : Viking Press/London/Oxford University Press. 